\title{
Glacial and lake fluctuations in the area of the west Kunlun mountains during the last 45000 years
}

\author{
Li SHiJie AND SHi YAFENG \\ Lanzhou Institute of Glaciology and Geocryology, Academia Sinica, Lanzhou 730000, China
}

\begin{abstract}
There appear to have been several important glacial advances on the southern slope of the west Kunlun mountains, Tibetan Plateau, since 45000 a BP. Based on the record of alternating till and lacustrine sediments and ${ }^{14} \mathrm{C}$ determinations, these advances are dated to $23000-16000,8500-8000$, and 4000 $2500 \mathrm{aBP}$, and to the 16 th-19th century $\mathrm{AD}$, with regional variations occurring during each of the advances. The glaciation of $23000-16000 \mathrm{a}$ BP is equivalent to the last glacial maximum (LGM) and its scope and scale were much larger than any of the others.

Lake changes are a response to both tectonic uplift of the plateau and global climatic change. With regard to the latter, both changes in precipitation and changes in the extent of glaciation can affect lake levels. High lake levels occurred during interstadial conditions between 40000 and 30000 a BP, when the area experienced a relatively warm and humid climate, and during the LGM, between 21000 and $15000 \mathrm{a}$ BP. During the Holocene, lakes have been shrinking gradually, coincident with the dry climate of this period of time.
\end{abstract}

\section{INTRODUCTION}

Qinghai-Xizang (Tibetan) Plateau is located in middleto lower-latitude regions with a mean elevation about $4000-4500 \mathrm{~m}$ a.s.l. Because of its geographical location and huge size it is a region that is extremely sensitive to changes in glaciers, lake levels, and permafrost, and thus can provide critical information about changes in climate and environment. Therefore, over the last ten years, many international cooperative investigations have been carried out on the plateau. Access to the west Kunlun mountains, however, is very difficult, and few field studies are available. Published information on the palaeoenvironmental history of the area is relatively scarce (for example, Li Jijun and others, 1986; Zheng, 1987; Li Shijie and others, 1989; Li Bingyuan and others, 1991).

This paper, based on field investigations and laboratory analyses of samples, provides some new evidence for glacier variations and lake changes since $45000 \mathrm{aBP}$ and uses this evidence as a basis for

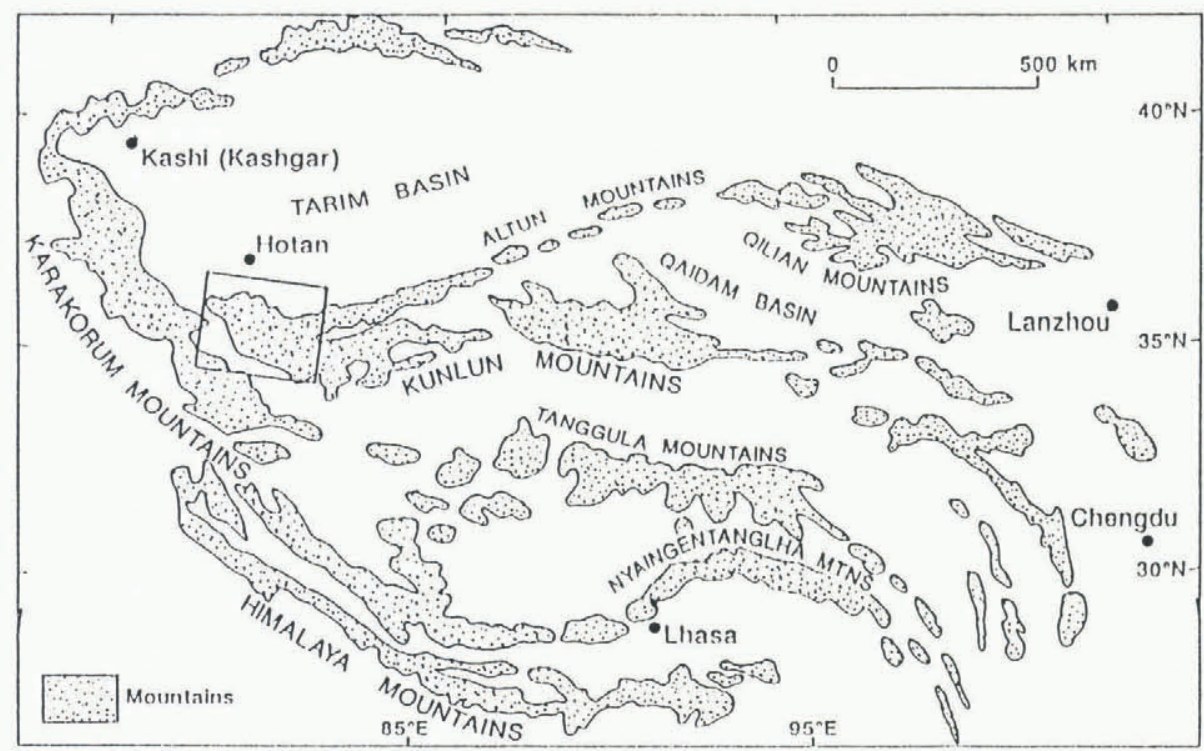

Fig. 1. Location of the west Kunlun mountains. Boxed region is enlarged in Figure 2. 
reconstructing palaeoclimatic and palaeoenvironmental changes.

\section{REGIONAL CHARACTERISTICS}

The west Kunlun mountains are a huge interior mountain range on the northwest margin of the Qinghai-Xizang Plateau (Fig. 1). They face the Tarim basin to the north and are adjacent to the Karakoram mountains to the west, and to a vast highland stretching to the south, with many peaks over $6000 \mathrm{~m}$ a.s.l. The highest peak in the range is Kunlun Peak, $7167 \mathrm{~m}$ a.s.l. (latitude $35^{\circ} 19^{\prime} \mathrm{N}$, longitude $80^{\circ} 55^{\prime} \mathrm{E}$ ).

The climate is very cold and variable, owing to the high altitude, with a mean annual temperature below $-5^{\circ} \mathrm{C}$. Thus, it is an area with one of the highest concentrations of existing glaciers in the world. According to statistical data of the Lanzhou Institute of Glaciology and Geocryology (1988), there are 4306 glaciers occupying a combined area of $8438 \mathrm{~km}^{2}$, of which 244 glaciers occupy $1347.67 \mathrm{~km}^{2}$ in the area along the south slope from Tianshuihai to Keriya Pass (Fig. 2). Most are valley glaciers, but some larger ice caps exist on the flat-topped summits. The glacial tongues generally reach to the mountain foot, about $4900-5300 \mathrm{~m}$ a.s.l. and the elevation of the modern snowline is about 5900 $6100 \mathrm{~m}$ a.s.l.

Modern lakes lie mainly in tectonically depressed basins with an east-west orientation. From west to east, these are: north Tianshuihai, Tianshuihai, Aksayqin, Guozha, and Bangda Lakes (Fig. 2). Basic characteristics of these lakes are listed in Table 1. The water source is mainly glacial meltwater. In the summer season, torrential meltwater streams flow into the lakes, causing them to rise. For example, the water level of Guozha Lake rose $0.14 \mathrm{~m}$ from 19 July to 28 August 1987 , measured by the Sino-Japanese Joint Expedition using a fluviograph.

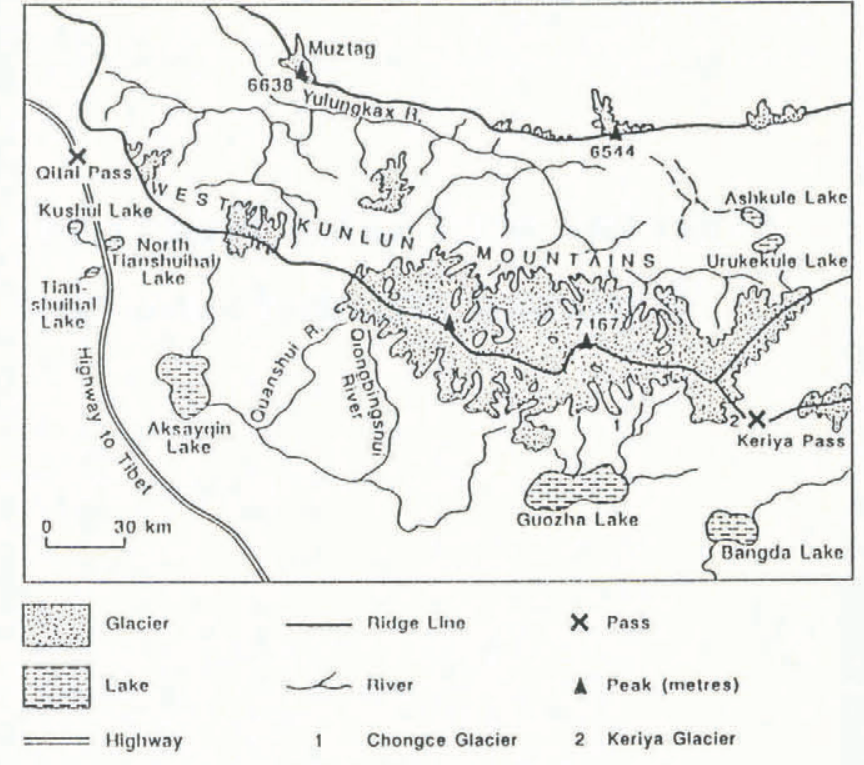

Fig. 2. Glacier distribution and location of lakes on the south slope of the west Kunlun mountains.

This required a minimum of $3416 \times 10^{4} \mathrm{~m}^{3}$ water, ignoring evaporation.

\section{GEOLOGICAL EVIDENGE FOR GLACIAL VARI- ATIONS}

\section{Glacial deposits}

Moraine systems can indicate glacial changes directly and record climatic fluctuations indirectly. But, in western China, it is more difficult to determine the ages of moraines because the till is composed mainly of boulders, sand and silt. Fortunately, stratigraphic sequences

Table 1. Characteristics of present-day lakes on the southern slope of the west Kunlun mountains

\begin{tabular}{|c|c|c|c|c|c|c|}
\hline Name & Lake level & Lake area & $\begin{array}{l}\text { Maximum } \\
\text { depth }\end{array}$ & Alkalinity & $\begin{array}{c}\text { Number of } \\
\text { glaciers }\end{array}$ & $\begin{array}{l}\text { Area of } \\
\text { glaciers }\end{array}$ \\
\hline & $\mathrm{m}$ a.s.l. & $\mathrm{km}^{2}$ & $\mathrm{~m}$ & $\mathrm{mg} \mathrm{L}^{-1}$ & & $\mathrm{~km}^{2}$ \\
\hline $\begin{array}{l}\text { North } \\
\text { Tianshuihai }\end{array}$ & 4800 & 4 & $<5$ & 1212.4 & 12 & 3.69 \\
\hline Tianshuihai & 4836 & 1 & 3.5 & & 10 & 1.80 \\
\hline Aksayqin & 4840 & 160 & 12.6 & 50531.98 & 129 & 709.08 \\
\hline Guozha & 5080 & 244 & 81.9 & 3840.96 & 62 & 544.34 \\
\hline Bangda & 4902 & 106 & 21.6 & 100393.96 & 90 & 170.34 \\
\hline
\end{tabular}



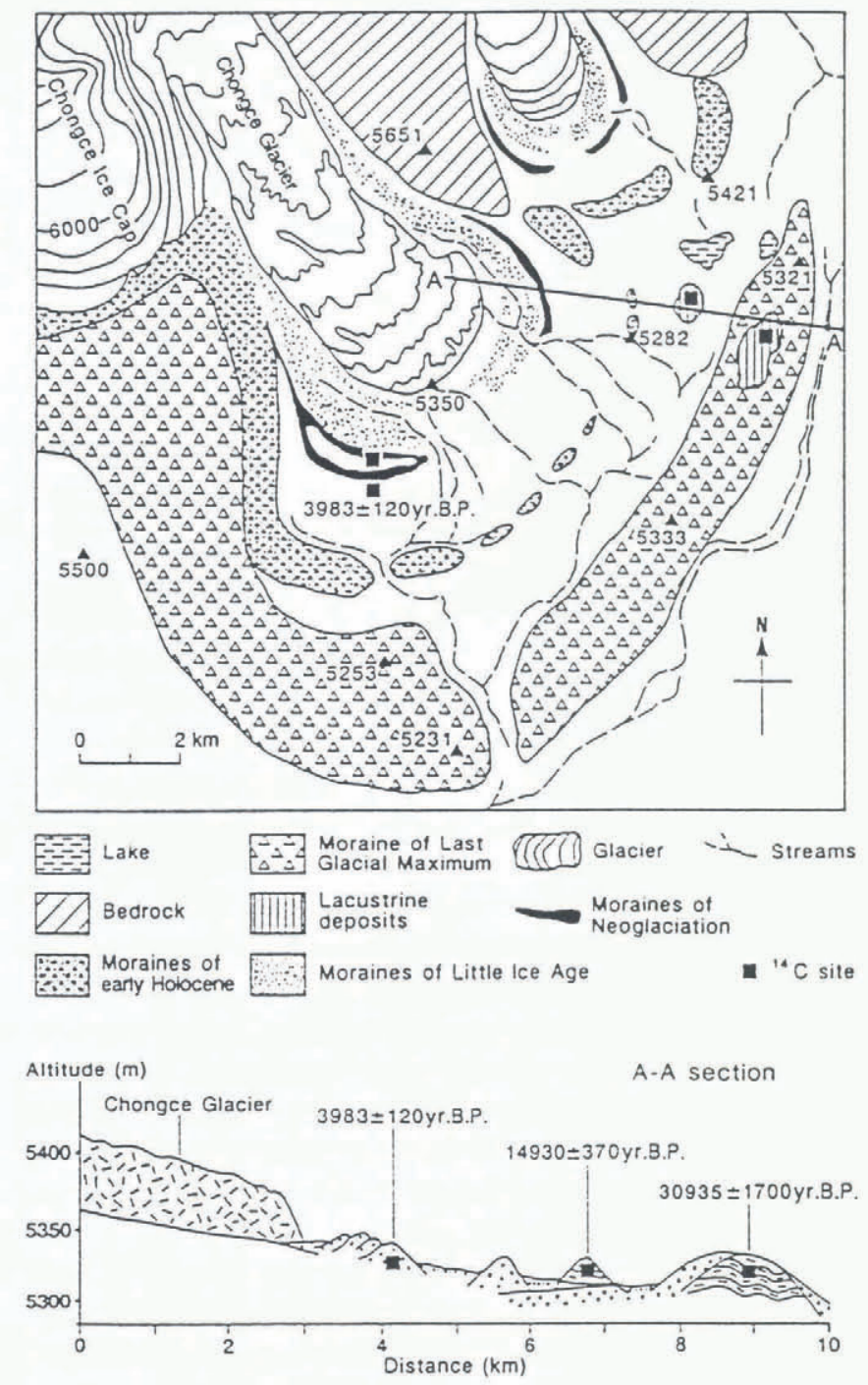

Fig. 3. Map of late Quaternary and Holocene deposits in the area of Chongce Glacier.

consisting of alternating till and lacustrine deposits, the latter composed of dark-grey clay containing macrofossils of aquatic grasses, have been discovered on the south slope of the west Kunlun mountains. Radiocarbon dates have been obtained from key sections. The following discussion is based on this chronology.

In front of the Chongce and East Chongce Glaciers ("1" in Fig. 2), north of Guozha Lake, there is a series of moraine ridges. Based on the stratigraphic sequence and chronology, they can be divided into several stages as shown in Figure 3. The first moraine, the LGM deposit, is arcuate in shape and lies about $6.5 \mathrm{~km}$ from the end of the Chongce Glacier. It has been eroded extensively by subsequent meltwater, and many boulders between 0.8 and $1.0 \mathrm{~m}$ in diameter are scattered on its surface. A 3 to $5 \mathrm{~m}$ thick outcrop of dark-grey lacustrine clay has been found beneath the moraine. At $1 \mathrm{~m}$ depth, the ${ }^{14} \mathrm{C}$ date is $30935 \pm 1700 \mathrm{aBP}$. In addition, another exposure of lacustrine clay was also discovered between the first and the second moraine. Its ${ }^{14} \mathrm{C}$ date is $14930 \pm 370$ a BP (Fig. 3b).

The second moraine, of Early Holocene age, is located about $3.5 \mathrm{~km}$ from the end of the glacier. It is composed of boulders, gravels, sand and silt. Streams have cut it into
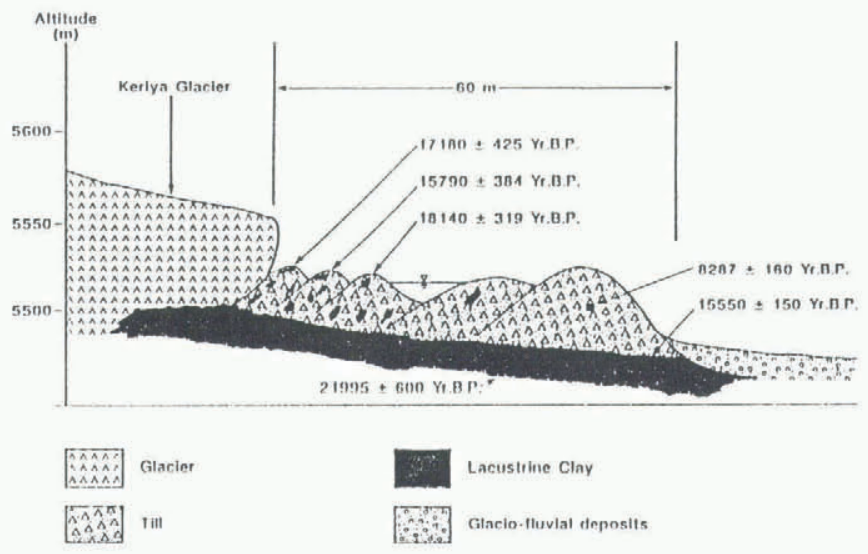

Fig. 4. Longitudinal profile through deposits at the end of Keriya Glacier. The 15-18ka dates from inner moraines are from older lacustrine material incorporated into moraines.

several separate hills with relief of about $5 \mathrm{~m}$, but the hills still surround the glacier tongue in an arcuate shape. On the surface, a thin soil layer has developed, and grasses grow on it. This moraine has not been dated, but an end moraine of similar character has been found in front of the Keriya Glacier ("2" in Fig. 2) at the Keriya Pass (Fig. 4). The latter's ${ }^{14} \mathrm{C}$ age is $8287 \pm 160 \mathrm{a}$ BP. Beneath this moraine, there are dark-grey lacustrine clay deposits with microlaminations. The ${ }^{14} \mathrm{C}$ age of organic material near the top of the clay is $15550 \pm 150 \mathrm{a} \mathrm{BP}$ and at $1 \mathrm{~m}$ depth it is $21995 \pm 600 \mathrm{a}$ BP. Some patches of dark-grey clay with ${ }^{14} \mathrm{C}$ dates of $15790 \pm 384,17180 \pm 425$ and $18140 \pm 319$ a BP were incorporated into the moraines formed by later glacier advances (Fig. 4). A synchronous end moraine, with a ${ }^{14} \mathrm{C}$ date, $8455 \pm 265 \mathrm{a} \mathrm{BP}$, has also been found at the Dunde Ice Cap in the Qilian mountains. This ice advance in China appears to be coincident with a cold period in the Early Holocene suggested by Denton and Karlén (1973).

The third and the fourth moraines of Chongce Glacier are neoglacial deposits, nearly connected with each other, about $1.2 \mathrm{~km}$ from the end of the glacier (Fig. 3). Distal parts have been destroyed by outwash. The wellpreserved lateral moraine ridges are about 5-8 $\mathrm{m}$ high and $30-50 \mathrm{~m}$ wide. Some grass has grown in patches where a thin soil has developed on the fine material. The ${ }^{14} \mathrm{C}$ ages are $3983 \pm 120 \mathrm{aBP}$ and $3522 \pm 117 \mathrm{aBP}$, respectively. In the Tien Shan mountains, northwest China, a similar end moraine of about $4080 \pm 150$ a BP ${ }^{14} \mathrm{C}$ age has also been found (Chen Jiyang, 1987). Interestingly, this is consistent with the dramatic demise of pine in Scotland at about 4000 a BP (Bennett, 1984; Bridge and others, 1990). This may suggest that climate deterioration was contemporaneous in the northern hemisphere at that time.

The last three moraines represent the Little Ice Age and are about $1.2 \mathrm{~km}$ from the existing glacier terminus. Grasses have barely colonized these moraines, in distinct contrast with those formed earlier. This pattern is general along the termini of existing glaciers in west China. It appears to be identical with the results of glacial fluctuations during the Little Ice Age all over the world (Grove, 1988). 


\section{Changes of glacier length and equilibrium line altitude (ELA)}

From the locations of moraine ridges, length changes of Chongce Glacier since the LGM can be reconstructed (Table 2). During the LGM the glacier was only $23 \%$ longer than at present. Based both on moraine position and accumulation area ratios, the estimated maximum ELA lowering during the LGM was about $300 \pm 50 \mathrm{~m}$. This is similar to the ELA lowering during the LGM $(\leqslant 400 \pm 100 \mathrm{~m})$ in the Rongbuk valley on the northern flank of Mount Everest (Burbank and Kang, 1991), but strongly contradicts Kuhle's model $(1985,1987)$ for icesheet growth across the Tibetan Plateau.

There are two possible reasons for the unusually slight recession of glaciers in this area during the post-glacial period. (1) The rapid uplift of the Tibetan Plateau may have greatly reduced the post-glacial climate warming and glacier retreat, while, at the same time, the largescale uplift of the peripheral mountains reduced the precipitation increase. (2) The conservative behaviour of glaciers of the extreme continental type, especially the low ice temperature and velocity as well as the low level of mass balance, results in smaller glacier variations.

\section{STRATIGRAPHIC RECORD OF LAKE CHANGES}

The evolution of the lakes on the southern slope of the west Kunlun mountains is a cumulative result of both the uplift of the Qinghai-Xizang (Tibetan) Plateau and global climate change. Intensive uplift of the plateau during the Quaternary has produced a barrier, obstructing transport of water vapour carried by the south Asia
Table 2. Length of Chongce Glacier at different times since the $L G M$

\begin{tabular}{lllll} 
Present & Little Ice Age & $4 \mathrm{kaBP}$ & $8-8.5 \mathrm{kaBP}$ & LGM \\
\hline & & & \\
$\mathrm{P}$ & $\mathrm{P}+1 \mathrm{~km}$ & $\mathrm{P}+1.2 \mathrm{~km}$ & $\mathrm{P}+3.5 \mathrm{~km}$ & $\mathrm{P}+6.5 \mathrm{~km}$ \\
$(28.7 \mathrm{~km})$
\end{tabular}

$\mathrm{P}=$ present

monsoon into the interior, and leading to a gradually drier climate. Meanwhile, this process has been superimposed on a background of global climatic change, which has resulted in regional climate changes similar to those of other places in the world, except for their amplitude.

Based on a vast area of lacustrine deposits, high lakeside terraces and a few age estimates, there was a large lake, termed palaeo-Tianshuihai Lake, in the foreland basin of the south slope of the west Kunlun mountains in earlier times. It was approximately $3000 \mathrm{~km}^{2}$ in area, whereas the total area of present-day lakes is only $410 \mathrm{~km}^{2}$, or $\sim 14 \%$ of the ancient lake area. By the Late Pleistocene, the palaeo-Tianshuihai Lake had shrunk, and the original water-filled basin changed into a vast lacustrine plain. This event is consistent with the history of most lakes on the Qinghai-Xizang Plateau (Chen Kezao and others, 1981). This is also demonstrated by two cores drilled, respectively, on a high terrace and at
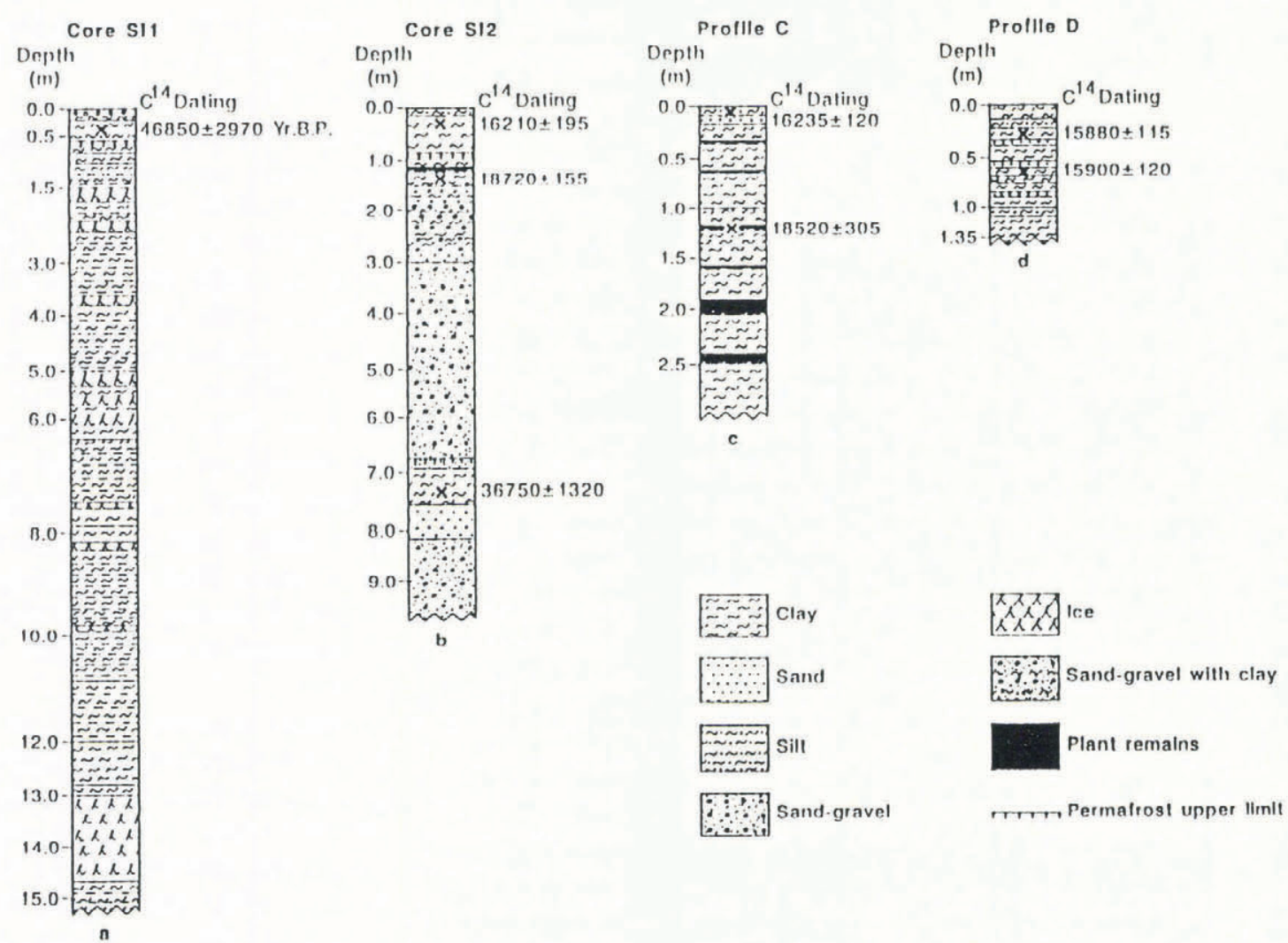

Fig. 5. Stratigraphic profiles of lacustrine deposits on the southern slope of the west Kunlun mountains. 
the present-day lakeside in the Tianshuihai area. One, $\mathrm{SI} 1$, was $15 \mathrm{~m}$ deep and the other, SI2, was $9.5 \mathrm{~m}$ deep (Fig. 5a, b). Core SIl, from the high terrace, is wholly composed of dark-grey lacustrine clay representing a stable lake sedimentary environment. $\mathrm{A}{ }^{14} \mathrm{C}$ date of bulk sediment near the top is about $46850 \pm 2970$ a BP, measured by the scintillation count method. The normal count time was doubled to obtain sufficient data to calculate the age. Thus, this age is probably unreliable. But there is no doubt that the core consists of older sediments.

The stratigraphic changes in core SI2, from the sandgravel layer at the bottom to a sand layer, thence to a dark-grey clay layer, thence to a sand-gravel layer, and finally to a dark-grey clay layer at the top, are interpreted to be sedimentary facies changes resulting from lake-level variations. The ${ }^{14} \mathrm{C}$ age of organic material in the lower dark-grey clay layer is about $36750 \pm 1320 \mathrm{aBP}$, and those of the upper clay layer are $18720 \pm 155 \mathrm{a} \mathrm{BP}$ and $16210 \pm 195 \mathrm{aBP}$ (Fig. 5b). There is also a layer of lacustrine clay in the high terrace section on the north shore of Aksayqin Lake. ${ }^{14} \mathrm{C}$ dating of organic material in it gives an age of $34735 \pm 820 \mathrm{a}$ BP. Based on the facies, these dates represent high stands of the lake, whereas the intervening sand and gravel layer represents a low stand.

Around all lakes, terraces are well developed and contain macrofossils of aquatic grasses which can be dated. In the first terrace section composed of lacustrine clay deposits around Aksayqin Lake, about 3 to $4 \mathrm{~m}$ higher than present-day lake level, ${ }^{14} \mathrm{C}$ dates of $18520 \pm 305$ a B at $1.25 \mathrm{~m} \mathrm{depth}$ and $16235 \pm 120 \mathrm{aBP}$ at the top have been obtained (Fig. 5 , profile c). In a section of the first terrace around Bangda Lake, consisting of alternate layers of dark-grey clay and fine-grained yellow sand, we obtained ${ }^{14} \mathrm{C}$ dates of $15900 \pm 120 \mathrm{aBP}$ and $15880 \pm 115 \mathrm{a} \mathrm{BP}$ (Fig. 5, profile d). There are also several well-developed lakeside terraces around north Tianshuihai Lake. The sedimentary section from the lakeside terrace to the basin bottom consists of sand and gravels of near-shore facies, sand and silt of shallow-water facies, and clay of deep-water facies (Fig. 6). ${ }^{14} \mathrm{C}$ dates on bulk sediments gave age estimates of $17480 \pm 155 \mathrm{aBP}$ and $17700 \pm 175 \mathrm{aBP}$ in the upper terrace, and $17360 \pm 180 \mathrm{aBP}$ in the lower one. These dates suggest that the terrace, about $40 \mathrm{~m}$ higher than present-day lake level, was formed during the period of
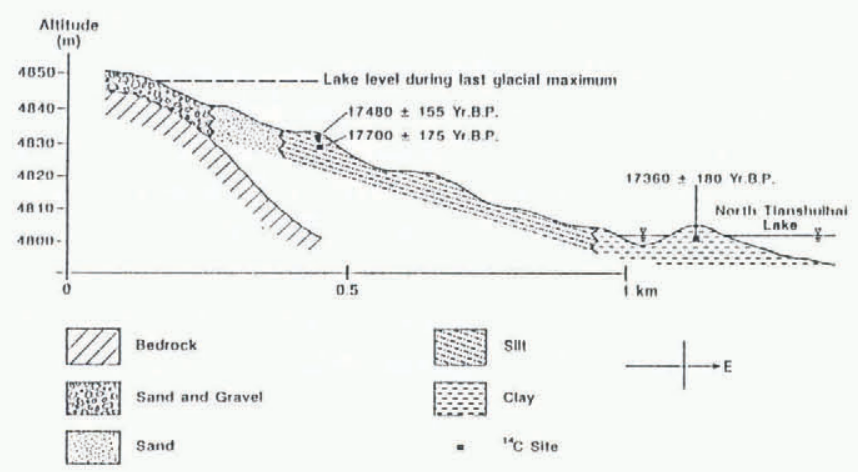

Fig. 6. Profile across lakeside terrace on north Tianshuihai Lake. the LGM, while the others formed subsequently as the lake was shrinking.

\section{DISCUSSION}

(1) Glacier advances and retreats depend mainly on mass-balance changes resulting from climatic change. Under the extreme continental conditions in the west Kunlun mountains, glacier variations are more sensitive to precipitation changes than to temperature changes because of the very cold average temperatures at these high altitudes. Thus, the period of glacier advance at the beginning of the LGM might indicate colder, wetter conditions, while glacier retreat during the late glacial suggests a dry climate. During the transition period, glacier stability could represent cold and dry climatic conditions. Moraine deposition should occur during periods of glacier stability and/or retreat under cold conditions.

Based on the record of glacial sediments during the LGM in the west Kunlun mountains, we can divide the glaciation into three main episodes: (i) glacier expansion, 23000 to 20000 a BP; (ii) glacier stability, about 20000 to $16000 \mathrm{a}$ BP and (iii) glacier retreat, from $16000 \mathrm{a} \mathrm{BP.}$

Regarding the glacier advance proposed for Early Holocene, our results represent only initial Chinese discoveries at a few sites. More detailed work is required to confirm it.

Following the climate optimum in the Middle Holocene, glaciers advanced in the west Kunlun mountains at about $4000 \mathrm{a}$ BP. This may be regarded as the beginning of a so-called neoglaciation.

(2) Lake-level changes in the west Kunlun mountains are closely related to both climate and glaciofluvial activity. Because most of these lake basins are closed hydrologic systems, their water balance depends on the balance between the amount of precipitation and meltwater influx, and the amount of evaporation. Lake-level changes can be identified by changes in sedimentary facies. Based on lacustrine stratigraphic records, there are two main periods of lake expansion during the last 45000 years. One was 40000 to $30000 \mathrm{a} \mathrm{BP}$, which is coincident with the warmer and wetter climate during the last interstadial. The level of Tianshuihai Lake during this stage was $60 \mathrm{~m}$ higher than at present ( $\mathrm{Li}$ Bingyuan and others, 1991). During this period, Qarhan salt lake in the Qaidam basin, one of the driest closed basins in China, contained fresh water and was much larger than at present (Chen Kezao and Bowler, 1987). Another period of lake expansion occurred within the LGM. The level of north Tianshuikai Lake was then $40 \mathrm{~m}$ higher than at present (Li Shijie and others, 1989). This is correlated with the high lake-level stage of 22500 to $20000 \mathrm{a} \mathrm{BP}$ throughout China suggested by Fang (1991).

The causes for the lake-level rises in the different stages are not the same. During the last interstadial, lake-level rise resulted from the warm and wet climate, while the lake-level rise in the earlier stage of the LGM, being synchronous with glacial expansion, indicates a cold and wetter climate. This was a period when a great quantity of water was transferred from the sea to the continents and stored in the form of ice. However, the maintenance 


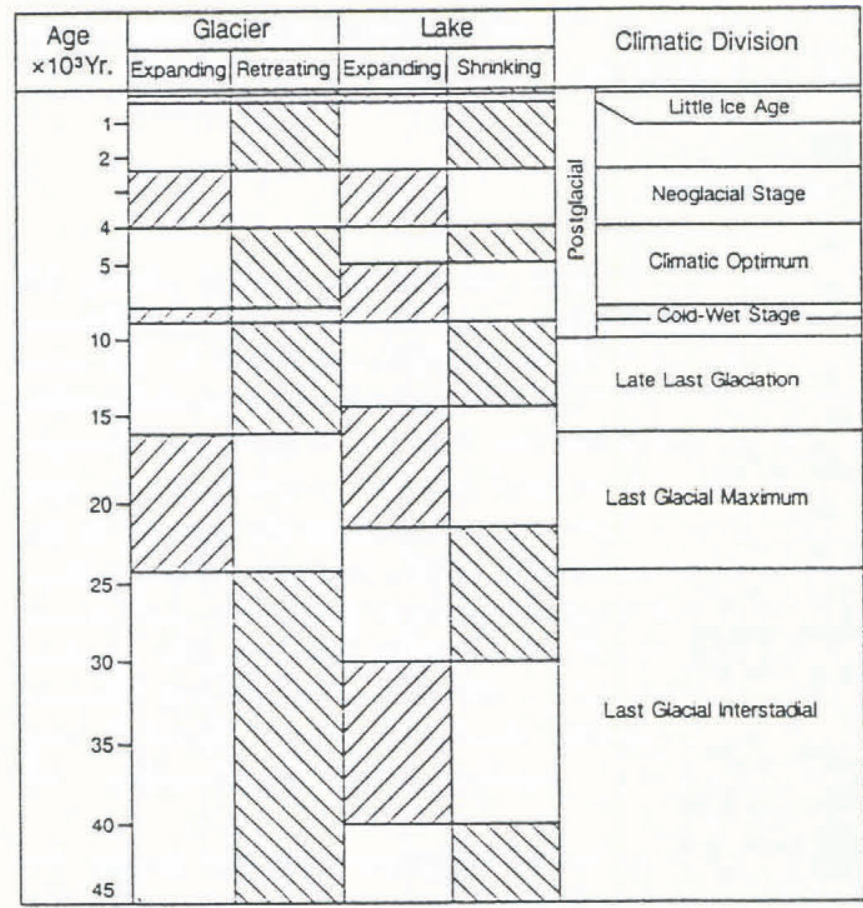

Fig. 7. Relationships among the glacial, lake, and climatic changes on the south slope of the west Kunlun mountains.

of a high lake level later in the stage, when the climate was warmer and drier, could result directly from the amount of meltwater flowing into the lake basins exceeding the amount of evaporation.

(3) Based on the discussion above, we summarize the relationship among the glacier, lake-level and climate changes in the west Kunlun mountains in Figure 7. Because Kuhle's estimates of the equilibrium line altitude depression and glacier geometries are completely irreconcilable with the results from this area, we suggest that his unified ice-sheet model for the Tibetan Plateau is not viable.

\section{ACKNOWLEDGEMENTS}

Many thanks to the Sino-Japanese Joint Glacial Expedition to the west Kunlun mountains, 1987, for offering us an opportunity to do the field investigation. The authors thank especially Dr R. LeB. Hooke and two anonymous reviewers for their very helpful suggestions for improving the manuscript and for their careful revision of the English text. Thanks also to Mr Zhang Yutian and $\mathrm{Mr}$ Cao Jixiu in the ${ }^{14} \mathrm{C}$ Laboratory of the Geography Department of Lanzhou University, and Mr Gu Gonshu in the ${ }^{14} \mathrm{C}$ Laboratory of Lanzhou Institute of Glaciology and Geocryology, for dating samples, and to Mr J. Jacyno for drafting.

\section{REFERENCES}

Bennett, K. D. 1984. The post-glacial history of Pinus sylvestris in the British Isles. Quaternary Science Reviews, 3, 133-155.

Bridge, M. C., B. A. Haggart and J.J. Lowe. 1990. The history and paleoclimate significance of subfossil remains of Pinus sylvestris in blanket peats from Scotland. 7. Ecol., 78, 77-99.

Burbank, D.W. and Kang Jiancheng. 1991. Relative dating of Quaternary moraines, Rongbuk Valley, Mount Everest, Tibet: implications for an ice sheet on the Tibetan Plateau. Quat. Res., 36(1), 1-18.

Chen Jiyang. 1987. The division of the Holocene moraine strata and their chronology in western mountainous area of China. 7. Glaciol. Geocryol., 9(4), 319-328. [In Chinese with English abstract.]

Chen Kezao and J. M. Bowler. 1987. Evolution of salt lakes in late Pleistocene in Qaidam Basin, Qinghai Province, China. In Committee of Sino-Australian Joint Quaternary Research, ed. Proceedings of SinoAustralian Quaternary Symposium (1984). Beijing, Science Press, 83-91. [In Chinese.]

Chen Kezao, Yang Shaoxiu and Zheng Xiyu. 1981. Saline lakes on the Qinghai-Xizang Plateau. Geographia Sinica, 36(1), 13-21. [In Chinese.]

Denton, G. H. and W. Karlén. 1973. Holocene climatic variations - their pattern and possible cause. Quat. Res., 3(2), 155-205.

Fang Jin-Qi. 1991. Lake evolution during the past 30,000 years in China, and its implications for environmental changes. Quat. Res., 36(1), 37-60.

Grove, J.M. 1988. The Little Ice Age. London and New York, Methuen.

Kuhle, M. 1985. Glaciation research in the Himalayas: a new ice age theory. Universitas, 27(4), 281-294.

Kuhle, M. 1987. Subtropical mountain and highland glaciation as Ice Age triggers and the waning of the glacial periods in the Pleistocene. Geojournal, 13(6), 129.

Lanzhou Institute of Glaciology and Geocryology. 1988. Glacier inventory of China VII. Beijing, Science Press, 73103. [In Chinese.]

Li Bingyuan, Zhang Qingsong and Wang Fubao. 1991. Evolution of the lakes in the Karakorum-west Kunlun mountains. Quaternary Sciences 1, 64-71. [In Chinese.]

Li Jijun. Zheng Benxing and Yang Xijin. 1986. Glaciers of Xizang. Beijing, Science Press. [In Chinese.]

Li Shijie, Zheng Benxing and Jiao Keqin. 1989. Preliminary research on lacustrine deposits and lake evolution on the southern slope of the west Kunlun mountains. Bull. Glacier Res. 7, 169-176.

Zheng Benxing. 1987. Preliminary studies of Quaternary glaciation and palaeogeography on the south slope of west Kunlun. Bull. Glacier Res. 5, 93-102.

The accuracy of references in the text and in this list is the responsibility of the author/s, to whom queires should be addressed. 